palpi narrow, yellow in the male and brown in the female. Thorax slender, pectus yellowish, pleuræ nearly glabrous. Abdomen narrow, male genitalia with two small spoon-shaped end-valves and central short penis, female abdomen tapering. Legs including coxæ pale yellow, the tarsi a little brownish, apex of hind femora and middle of hind tibiæ usually dusky. Halteres pale yellow, calypteres yellow, with long fringe. Wings narrow, three times as long as wide, hyaline, veins brown, first vein ending at basal third of the wing, second and third sections of the costa proportioned $2: 1$, sections of fourth vein nearly $1: 2: 3$, the last section arching forward but apically becoming parallel with the third vein, anal vein extending two-thirds the distance to the margin, anal crossvein recurved at tip.

Twelve specimens. Type from Potlatch, on Hood's Canal, Wash., July 28, 1917; others from Blaine, Lynden and Auburn, Wash., and Lake Coeur d'Alene, Idaho, July to September. Several of the specimens were found on windows.

\title{
ON CERTAIN SPECIES OF HALTICA, OLD AND NEW.
}

\author{
BY H. C. Fall, \\ Tyngsboro, Mass.
}

About a year ago, after reading the then recently published paper $^{1}$ by William Colcord Woods on the life histories of certain Maine Halticas previously regarded as varieties of $H$. ignita Illig., and having examined typical examples of all forms, kindly sent by Mr. Woods, some observations seemed pertinent to the writer, but the matter was allowed to go by default, and nothing was done beyond communicating one or two points to Mr. Woods by letter, chief of which, perhaps, was the fact that his Haltica torquata was not the torquata of Le Conte.

More recently comes Mr. Malloch's article, ${ }^{2}$ in which he, too, alludes to the probable error in identifying the eastern blueberry flea beetle as Le Conte's torquata. Although Mr. Leng frankly admits his responsibility for the mistaken identification, he is by no means the first offender, as the torquata mix-up really dates back to Horn's Synopsis of the Halticini in 1889, in which he erroneously

1 Maine Agric. Exp. Station Bull., 273; October, 1918.

${ }^{2}$ Bull. Brooklyn Ent. Soc. XIV, p. 123. 
suppresses the name as a synonym of carinata Germ. As a matter of fact, in the series of carinata in the Horn collection the name label $i s$ attached to a specimen of torquata bearing the locality label "Bengtn Co., Vt." The type of torquata came from Santa Fé, New Mexico (not from Kansas as Malloch says), and while I have seen scores of specimens from New Mexico, Arizona, Nevada and California, I have as yet to see an example from anywhere east of the type locality. Mr. Malloch has specimens from western Kansas which he believes to be the true torquata. If he is correct in his identification, this must I think, be the eastern limit of its range; but I strongly suspect his specimens are representatives of an unnamed species which is associated with torquata in collections and which will be described in the present article.

The accuracy of the "Vt." label on the Horn specimen may, therefore, be most seriously questioned, the more so, since this is only one of a number of species ranging from the seashore to the western deserts, which bear the impossible label "Bengtn Co., Vt." These all come from the same collector, who undoubtedly mixed material from various sources, and then, perhaps long after, carelessly attached the same locality label to the whole bunch. It, therefore, behooves students of distribution to look with a very critical eye on this particular label before accepting it as genuine.

If, as all the available evidence seems to indicate, torquata does not occur east of the Rocky Mountains or vicinity, then it cannot be the carinata of Germar, which was described from Kentucky at so early a date that even accidental importation from the western plains or mountains is out of the question. Unfortunately Germar's description of carinata is too short and indefinite to be of much service, but it fits as well as any other the carinata of the Le Conte collection, which is also (and probably in consequence) the carinata at least in part of the most reliable modern collections, and of numerous bibliographical references. In the absence of any definite contradictory evidence this species should continue to bear the name carinata. It is not at all similar to torquata, but is closely related to chalybea and ignita; it is the ulmi of Woods.

In the Horn Collection specimens of this species are included both with torquata in his carinata series and with his ignita series. The former association is difficult to understand, as they do not at all closely resemble one another, but it explains two confusing 
statements in his Synopsis. In the table of species carinata is characterized as having the ante-basal groove of the thorax moderately deep, evanescent at the extremities and never entire. In the remarks preceding the table of species he says that specimens of carinata occur with the impressed line as entire as in chalybea. The former statement, as well as the words "bright coppery red with bluish or purplish reflections," is evidently drawn from torquata, while the latter statement applies to the true carinata. Incidentally it may be remarked that the expressions, "ante-basal groove deep and entire" or "moderate and not entire," which look quite definite and satisfactory on the printed page, are really very difficult to apply in practice. Looked at from one position you unhesitatingly pronounce the groove entire, but viewed from a different angle you are quite as positive it isn't. The only course left to you is to try both roads, but this is no unusual thing in the use of taxonomic keys. But to come back to the H. torquata of Woods; if this is not the true torquata, what is it? Malloch has assumed it to be an undescribed species, and has proposed the name sylvia. This action I fear is premature. A specimen taken by myself at Tyngsboro, Mass., September 1, 1916, has been compared by me with Blatchley's type of cuprascens and proved so closely similar that I felt no hesitation in attaching that name to it. A Michigan example sent me by Dury, and others from Michigan, recently seen in the National Museum Collection are quite certainly the same thing, and I have little doubt are identical with Blatchley's type.

That very careful and painstaking work was done by Mr. Woods on the biologies of the Maine Halticas is obvious from a perusal of his report, which constitutes a valuable contribution to the recorded life histories of our coleoptera. The results of his work have thoroughly convinced him of the specific distinctness in all stages of three forms " that in Horn's Monograph would fall under the single species ignita Illig." To these he gave the names corni, rose and $u l m i$. As has been stated above, $u l m i$ is to the best of our belief the carinata of Germar, so that two only are created at the expense of ignita. The writer has for some time inclined to the belief that the ignita complex would ultimately be broken up into a number of distinct species by more careful study coupled with an association with their food plants; he is, therefore, disposed to 
accept the conclusions of Mr. Woods, at least until further evidence is forthcoming. On the other hand it must be conceded, that aside from color and size, which may mean much or very little, the differences as presented are all very small and not entirely constant. While a difference in food plant is always suggestive, it is of course by no means necessarily indicative of specific distinctness, the accompanying differences in color, etc., being quite conceivably no higher than racial in character. Mr. Woods' experiments show that the larvæ of all the forms studied could be induced to feed more or less readily on a considerable variety of plants. Apparently no effort was made to carry them through to maturity on any other than their preferred food plant, though the results of such effort, especially if successful, would have been of great interest, as would the results of attempts at cross breeding. Such experimentation is often difficult of accomplishment, and under the most favorable conditions involves skilled handling and a great deal of time. It is to be hoped however that Mr. Woods or some equally competent investigator may continue the work so well begun.

It should be noted that two statements in Woods' "Key to the Adults," on page 154, are more or less misleading. The antennæ of ulmi are said to be "one-half the length of the body." This certainly is not always true, since in one of the two typical examples sent me the antenna is extended along the side of the body in good position for comparative measurement and is quite three-fifths as long as the body. Again, the so-called "ignita of Chittenden" is said to have "segment 3 of the antennæ longer than segment 4." This is not true of any Haltica in our fauna, unless possibly as an accidental individual variation.

In this connection it becomes of interest to know just what the "ignita of Chittenden" is. Referring to his article on "The Strawberry Flea-Beetle"1 it appears that so far as the beetle is described, it is the broadly conceived ignita of Horn's Synopsis, varying in color "from bright metallic golden, coppery, golden brown or purplish, to green and blue" and ranging in distribution from ocean to ocean and from Canada to Mexico. This does not help us any, but some observations made further on in the account of the life history as worked out by the author, supplemented by numerous specimens and some additional data kindly submitted to me by

\footnotetext{
${ }^{1}$ Some Insects Injurious to Garden Crops, Bull. 23 N. S. U. S. Dept. Agric. 1900.
} 
Dr. Chittenden himself, show conclusively the species which may properly be called the "ignita of Chittenden," that is to say, the species whose life history he portrays is the $H$. litigata described some ten years ago by the writer, from Florida specimens. In the material from the Department Collections, sent me for examination by Dr. Chittenden, there are many of this species which so far as known to me ranges from the District of Columbia and Ohio to Florida and Texas, and is evidently common or even abundant in this region, and though partial to strawberry, the beetles at least are inclined to be quite polyphagous, especially when swarming. The pin labels on specimens sent by Chittenden indicate the occurrence of the species on rose at Biloxi, Miss.; on Enothera biennis, "reared from egg indoors," Biloxi, Miss.; on crêpe myrtle at Norfolk, Va., and Melbourne, Fla.; on strawberry at Orlando, Fla., Bellemont and Paget, Bermuda, and Tickfaw, La.; on turnip, Bee County, Tex.; on lettuce and on Gaura sinuata at Brownsville, Tex.; on Fuchsia at Washington, D. C. There is no mention whatever of larvæ in the departmental notes relative to the above, except in the case of Gaura sinuata at Brownsville, where on March 5,1909 , were found "larvæ eating leaves" and eggs also collected. Gaura is nearly related botanically to Enothera, and both are undoubtedly natural food plants of this insect.

Referring now to the biologic records, pages 74-76 of Bulletin 23, we may say with considerable certainty that in all mentioned cases of injury to strawberries in Florida, North Carolina, Maryland and Indiana, and to Fuchsia at St. Louis, Mo., the culprit was $H$. litigata. The species reported as feeding on grape at Tempe, Ariz. (Insect Life, Vol. I, p. 220) is without much doubt the $\boldsymbol{H}$. torquata. This, under the name carinata, is also reported by Coquillet as feeding on grape at Los Angeles, Calif., and one of his specimens is now before me. The Minnesota "lesser grape vine flea-beetle" of Lugger is in all probability the "sixth" Maine species referred to by Woods, pages 150-151, and found by him on two occasions on woodbine. To this species Woods gave a manuscript name and sent me specimens suggesting that I describe it. On a recent visit to the National Museum at Washington, Mr. Schwarz showed me a long series of a new Haltica of which the life history had been worked out and a description written and already submitted for publication by Mr. Iseley of the Department of 
Agriculture. I believe this to be the same as Woods' sixth species and Lugger's grape vine species. As for Bruner's Nebraska species and Gillette's Colorado species nothing definite can be said; Chittenden's brief references give no clue and probably the original articles would be insufficient for identification even if they were accessible to me.

The species occurring on laurel, the kalmio of Melsheimer, I believe as did Horn, notwithstanding the mysterious "plica submarginali," to be the typical ignita of Illiger. It is highly improbable that a distinct species of Haltica with a normal submarginal elytral plica, but otherwise agreeing with our laurel species, can exist in the Atlantic region and no specimens of it have turned up in the more than one hundred years since Illiger published his description. In a recent conversation with Mr. Schwarz, he expressed the opinion that this elytral fold was apt to appear fortuitously in any species of Haltica, more especially in the females. Apropos of this observation, there are now before me three examples of a small Haltica ( $2 \sigma^{\text {T's }} 1$ \% ) recently sent me by Chittenden, in the female of which there is a tolerably well defined lateral elytral plica, while the males show slight traces of it. These specimens were collected at West Springfield, N. H., on Lombardy plum. They resemble greatly and probably are the $H$. roso of Woods; however, they diverge slightly from my typical examples of rose, and in the direction of ignita (kalmice Melsh). What I take to be typical examples of the latter differ from typical roso in their more brilliant color, slightly larger size, more coarsely punctate elytra, and in having the hind margin of the thorax slightly sinuate each side of the middle so as to present a small median lobe. In my typical roso there is no trace of such a lobe, but this character is probably not entirely constant, nor are either of the others very dependable. In addition to typical rose, corni and ulmi, I received from $\mathrm{Mr}$. Woods specimens of another form, of which he wrote as follows: "I have taken another member of the ignita group on laurel and am sending specimens under separate cover. I am calling it kalmice MS. This runs close to rose in every character, as far as eggs, larvæ and pupæ are concerned." From the above it must be obvious that rose and ignita (kalmio Melsh = kalmice Woods MS.) are exceedingly close if actually distinct, and that the Lombardy plum female with the submarginal plica might serve very well for 
the type of Illiger's description. It will be of interest to note that laurel was not among the food plants offered the roso larvæ in Woods' experiments, but that wild plum was offered and refused.

The following additional biologic notes gleaned from the material sent me by Chittenden may well be put on record at this time, but it should be borne in mind that unless otherwise stated it is only the beetles that were found upon the plants, and that in some instances, at least, the visitation probably has no economic significance whatever.

H. bimarginata Say. Intervale, N. H., bred from alder; Gardiner,

Me., collected on alder; Brownsville, Tex., feeding on willow; Guadalupe, Cal., on willow. This is the well-known alder fleabeetle; its occurrence on willow is more exceptional.

H. carinata Germ. Mont Alto, Pa., on elm.

H. chalybea Ill. Orlando, Fla., and Warrenton, Va., on grape.

H. evicta Lec. Moscow, Idaho, on strawberry.

H.foliacea Lec. Tecumseh, Okla., "Coll on apple"; Garden city, Kans., "feeding on weeds"; Childress, Tex., "on sugar beets." H. knabii Blatch. Marshall Hall, Md., reared from larvæ taken in field on Enothera biennis. The specimens bear the label $\boldsymbol{H}$. fuscornea Melsh, as they probably do in other collections.

H. probata Fall. San Luis Obispo, Calif., "on wild rose."

H. suspecta Fall. Corcoran, Calif., "on sugar beets."

H. vicaria Horn. Fort Collins, Colo., "Sugar beets." I do not think it likely that either of the last two species attack beets in the larval stage or that the beetles will prove a menace to crops.

To the systematist the genus Haltica offers very great difficulties; hence the especial need for the illumination which the complementary work of the biologist may shed upon the obscure relationships of the ignita group. While we have as yet no record of the food plant or habits of $\boldsymbol{H}$. incrata Lec. of the Manitoba region, an examination of the type convinces me that it should be restored to specific standing. It should probably be associated with ignita and allies, but it differs more from either ignita, roso or corni than they do from each other. The ante-basal groove of the thorax, though entire, is less deep than in either of these, the form rather narrower and less broadly shouldered, the color brown bronzed, the elytra typically with a faint greenish reflection which is often lacking. The resemblance of incrata to obolina of the Pacific 
region is more marked than to any of the eastern forms, but the basal impression of the thorax is much stronger than in the latter. I have seen a good series of incrata collected at Winnipeg and Husavick, Manitoba (Wallis).

There are yet a considerable number of probably new species in my collection, of which the following four may I think be described at this time in a recognizable manner.

\section{Haltica purpurea sp. nov.}

Oval, moderately elongate, dark bronze, the elytra with distinct purple lustre, surface shining. Head and thorax very finely alutaceous, varying to scarcely visibly so; elytra distinctly alutaceous. Antennæ piceous, about $\frac{3}{5}$ as long as the body, 4th joint slightly to scarcely longer than the $3 \mathrm{~d}$, fully twice as long as wide; 10th not quite twice as long as wide. Head $\frac{3}{5}$ as wide as the prothorax, eyes only moderately prominent, their width as seen from the front evidently less than half the interocular distance; vertex contiguous to the flattened tubercles smooth, almost without punctures. Prothorax $\frac{2}{3}$ as long as wide, sides narrowly margined, narrowed in front, subparallel in basal half and either with or without a feeble sinuation before the hind angles; punctuation sparse and minute, ante-basal impression fine and sharply defined, but not deep and not quite attaining the sides. Elytra distinctly oval in outline, widest at the middle, not quite $\frac{1}{2}$ wider than the thorax in the male, the female a little stouter; punctuation much more distinct than that of the thorax, but rather fine, the punctures separated on the average by about twice their own diameters, intermixed finer punctures almost entirely lacking. Body beneath and femora piceous, more or less distinctly purpureous; tibiæ and tarsi scarcely metallic. Last ventral of male with the usual apical lobe and smoother median impression. Length, 3.3 to $3.8 \mathrm{~mm}$.; width, 1.8 to $2.1 \mathrm{~mm}$.

Described from a series of $30^{7 \text { 's, }}, 1 \%$, taken at Tyngsboro and near Lowell, Mass., by the late Frederick Blanchard, from whom I received them.

An attempt to place this species by Horn's table through a strict interpretation of the characters there used is likely to prove abortive. The oval form of the elytra is quite suggestive of the much larger californica and obliterata, as well as cuprascens Blatch. 
and the smaller fuscocenea. My suggestion would be that these five species together with heucherce sp. nov., the description of which follows, should be associated in the following order: obliterata, californica, cuprascens, purpurea, heuchrce, fuscoønea. Purpurea is probably nearest cuprascens, the latter differing in its cupreous coloration, rather larger size and more elongate form, feebler pronotal groove, usually finer elytral punctuation and longer fourth antennal joint, which is three times as long as wide and decidedly longer than the third joint. There are numerous specimens of this species in the Blanchard Collection, now in the Museum of Comparative Zoölogy at Cambridge, Mass. The type is a male labeled "near Lowell, Mass."

\section{Haltica heucheræ sp. nov.}

Moderately elongate, head and thorax cupreoæneous, with feeble violaceous lustre, elytra distinctly purpureo-violaceous. Antennae scarcely more than half the length of the body, piceous, joints 2-4 testaceous, several of the following joints more or less rufous basally; joints 3 and 4 subequal, the latter at most only slightly longer, 4th joint twice as long as wide, 10th scarcely more than $\frac{1}{2}$ longer than wide. Head smooth, polished; eyes smaller than usual, feebly prominent, their width as viewed from the front much less than half the interocular distance. Prothorax quadrate, less than $\frac{1}{2}$ wider than long, sides parallel, rather strongly margined, feebly arcuate medially, surface finely alutaceous, and finely rather sparsely punctate; ante-basal groove moderately deep and practically entire. Elytra suboval, humeri narrow and broadly rounded, sides feebly arcuate or ( $\sigma^{x}$ type) straight and parallel for a short distance at middle; surface distinctly alutaceous and rather coarsely punctate, intermixed finer punctures scarcely evident. Body beneath and legs, except tarsi, piceous with purplish surface lustre. Male with the last ventral segment lobed and impressed as usual. Length, 3.5 to $3.8 \mathrm{~mm}$.; width, 1.7 to $1.85 \mathrm{~mm}$.

Described from four examples (type $\sigma^{7}$ ) collected by Mr. Norman Criddle at Aweme, Manitoba "25-IX-1916," on Heuchera hispida. The specimens were sent me by Mr. J. B. Wallis, in whose collection are paratypes. The quadrate thorax and oval elytra suggest association with fuscoænea, before which this species may be placed as indicated in the remarks following the preceding 
description. It is much larger than fuscoxnea, of different color, with smaller less prominent eyes, more distinctly punctate thorax with deeper ante-basal groove, and entirely dark legs.

Haltica blanchardi sp. nov.

Elongate oblong, green, elytra slightly, thorax rather strongly æneous. Antennæ a little longer than half the body; piceous, with slight metallic lustre; joints 3 and 4 subequal. Eyes prominent, their width as seen from the front nearly equal to half the interocular distance. Head above the frontal tubercles not visibly alutaceous and nearly impunctate. Prothorax $\frac{1}{3}$ wider than long, sides parallel in basal half, convergent in front, subangulate medially, side margin moderate, surface plainly alutaceous, distinctly though finely punctate, basal groove rather wide, vaguely attaining the sides, sharply impressed at bottom, this sharper impression terminating before reaching the margins; hind margin broadly angulate at middle. Elytra oblong, not quite twice as long as wide, sides parallel for $\frac{3}{4}$ their length, surface distinctly alutaceous and rather coarsely and closely punctate with scattered minute punctures intermixed. Body beneath and legs piceous with distinct purple metallic lustre. Length, $3.1 \mathrm{~mm}$.; width, $1.4 \mathrm{~mm}$.

Three examples only of this species are known to me; the type, taken by myself at Tyngsboro, Mass., July 6, 1893, and two other examples in the Blanchard Collection, also taken at Tyngsboro. In size and form it agrees very closely with amcena Horn and vaccinea Blatch., and with them only. In both these species the color is more decidedly cupreous, and in neither of them is the surface sculpture so marked as in blanchardi, which has a finely scabrous aspect. In amcena, described from a unique example from Georgia, the elytral punctuation is about as coarse but less dense than in blanchardi, the thorax obsoletely punctulate, the basal impression not quite so strong though quite sharply defined. Horn's statement that the antennæ are slightly longer than the body is a manifest inaccuracy, nor should I describe the humeri as oblique. The Floridian species vaccinea differs notably from blanchardi in its smaller less transverse prothorax, with nearly straight feebly converging sides, and with polished almost imperceptibly punctate surface. 
Haltica vialis sp. nov.

Oblong oval, color above and beneath including the legs purpureo-violaceous; sutural region especially toward the base, with greenish reflections. Antennæ dark throughout, feebly metallic, third and fourth joints subequal. Eyes not very prominent, their width viewed from in front less than half the interocular distance. Head smooth posteriorly; vertex, contiguous to the flattened tubercles coarsely punctate from side to side. Prothorax moderately transverse, a little narrower in front, widest behind the middle, sides broadly arcuate, feebly convergent basally, more noticeably so anteriorly; surface scarcely visibly alutaceous, closely comparatively coarsely punctate; ante-basal groove rather feeble, shallow and incomplete. Elytra oblong, slightly oval, sides very broadly arcuate, surface a little more coarsely punctate than the thorax but scarcely as closely so. Body beneath often with greenish reflections. Male with last ventral lobed as usual and with an unusually deep polished median longitudinal impression in posterior half. Length, 4.7 to $5.1 \mathrm{~mm}$.; width, 2.2 to $2.5 \mathrm{~mm}$.

The type is a male and is one of two examples taken by myself at Raton, New Mexico, November 8, 1889. The specimens were taken, if I remember correctly, under shelter of some sort near the railway station while stopping for lunch on my first transcontinental trip to California. I have since similarly taken the species at Seligman, Ariz., and have an example from Flagstaff, Ariz., taken by Dr. Fenyes. There are examples in the Le Conte Collection from Colorado and western Kansas (Popenoe), and in the Horn Collection from Colorado, in both cases placed with the superficially rather similar torquata, and both combined with the very different eastern carinata, a mix-up that it is certainly difficult to comprehend. Compared with torquata the present species is rather larger and more robust, with a much larger thorax and conspicuously coarser punctuation throughout. The ante-basal groove of the thorax is also less sharply defined and the last ventral of the male more deeply impressed. 

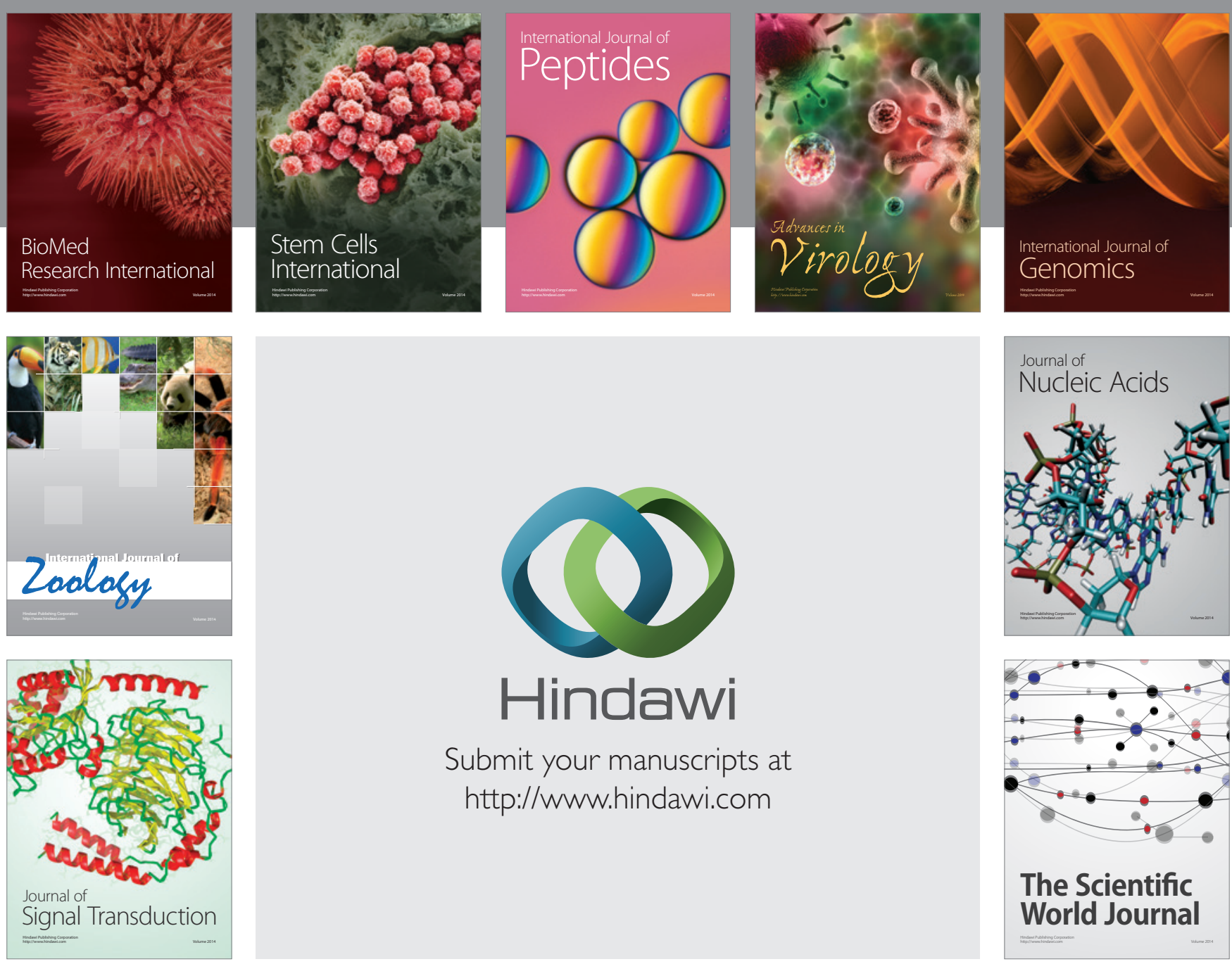

Submit your manuscripts at

http://www.hindawi.com
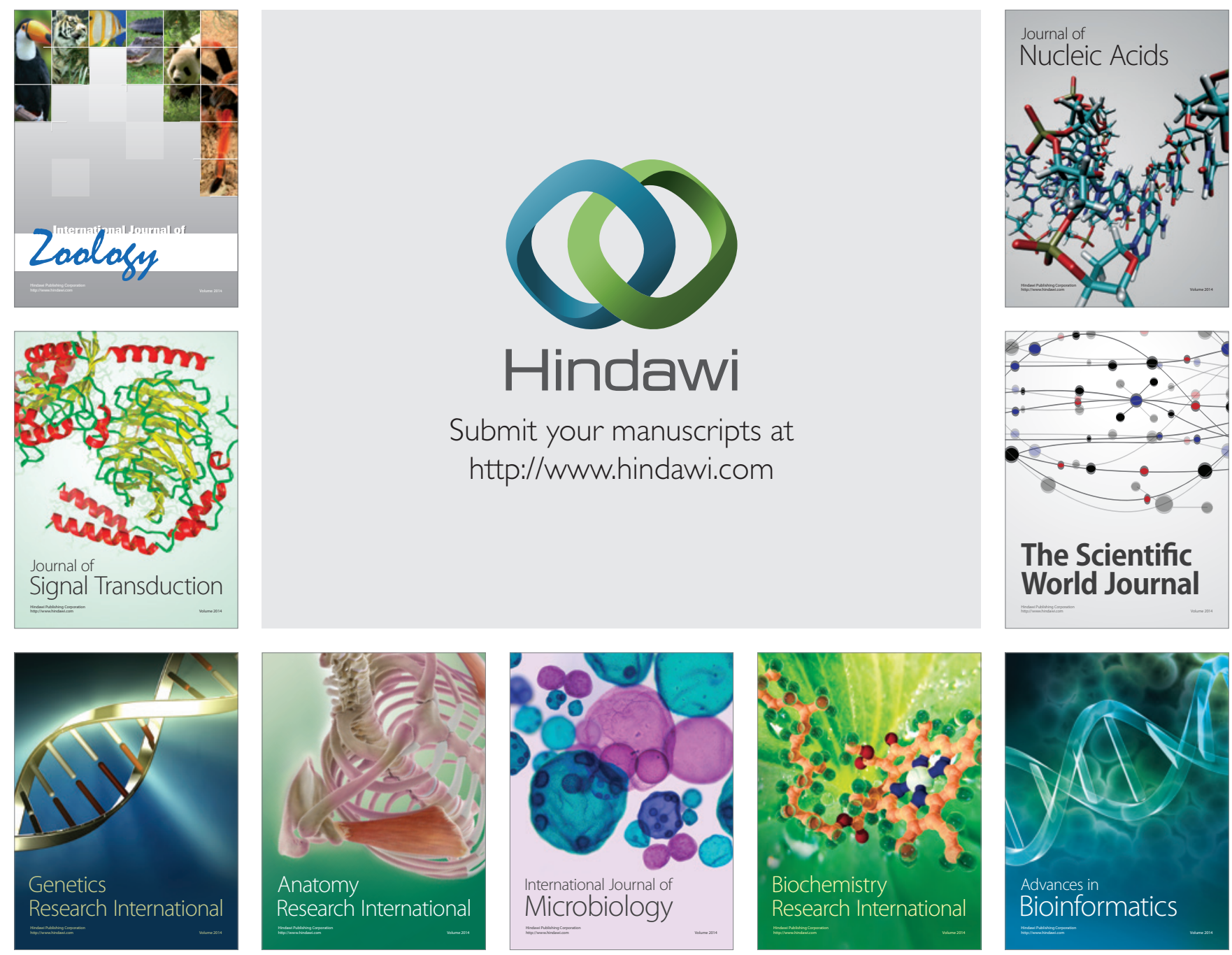

The Scientific World Journal
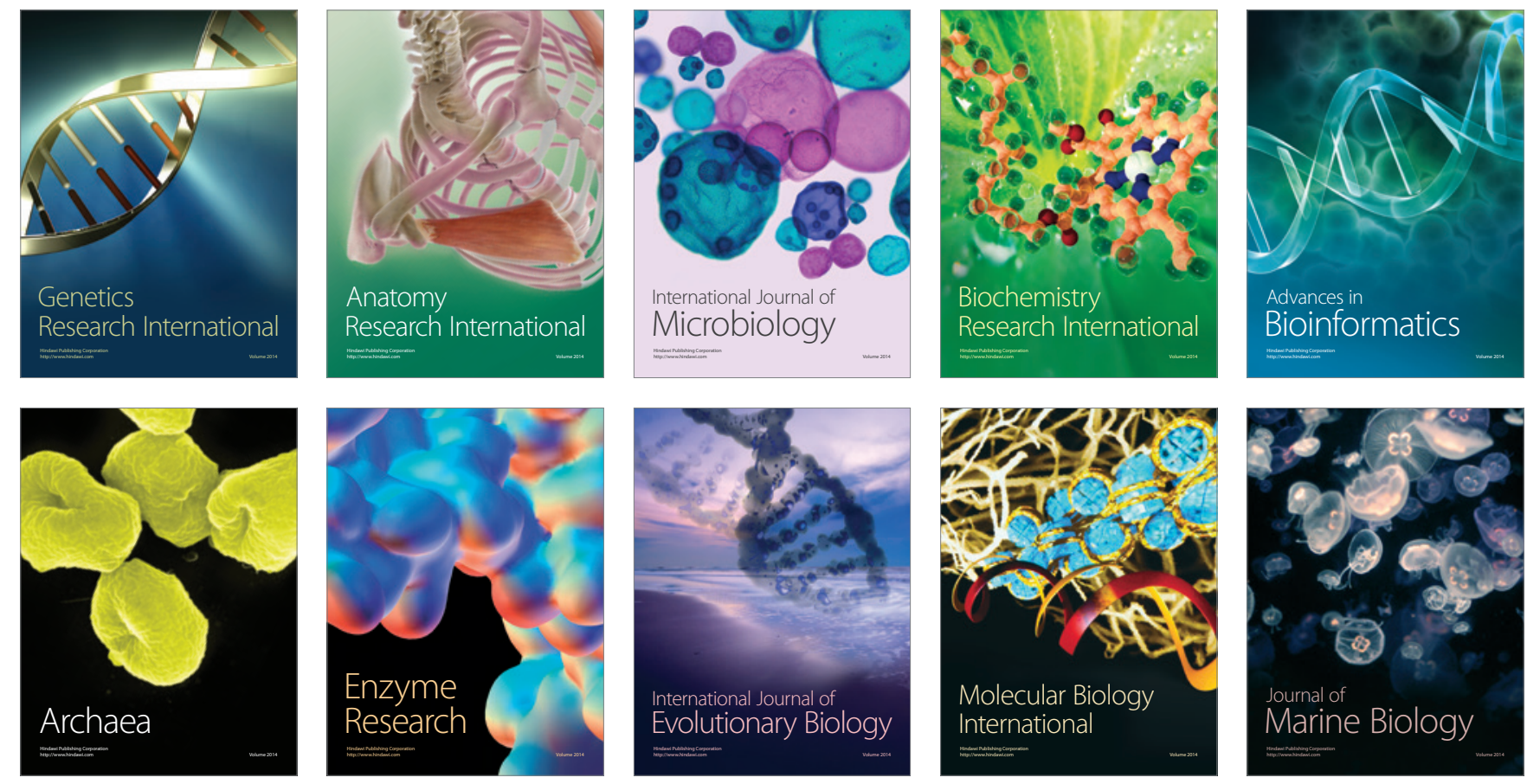